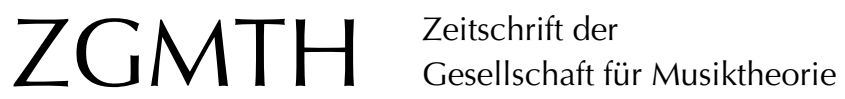

Caplin, William E. (2003/05): North American Approaches to Musical Form. ZGMTH 1-2/2/2-3, 139-142. https://doi.org/10.31751/519

(C) 2003/05 William E. Caplin

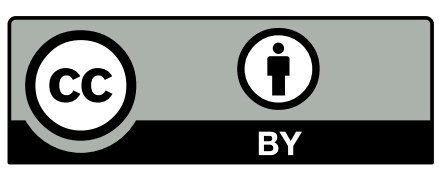

Dieser Text erscheint im Open Access und ist lizenziert unter einer Creative Commons Namensnennung 4.0 International Lizenz.

This is an open access article licensed under a

Creative Commons Attribution 4.0 International License.

veröffentlicht / first published: 01/04/2005

zuletzt geändert / last updated: 15/01/2010 


\title{
North American Approaches to Musical Form
}

\author{
William E. Caplin
}

Until recent years, the North American music-theoretical community has paid scant attention to the theory of musical form. In the early days of the Society for Music Theory (1970s-80s), speculative work on form was not only ignored by most theorists, but many developed a markedly antipathetic attitude toward the subject, most likely influenced in that respect by Heinrich Schenker's critique of the traditional "Formenlehres. As well, the two most popular textbooks used in music schools throughout the second half of the century - those by Douglass Green and Wallace Berry - broke little new theoretical ground.

In effect, theorists largely left research into musical form to historical musicologists, whose contributions can be roughly organized around three main lines of inquiry: (1) the "critical" writings of Charles Rosen, who builds upon Donald Francis Tovey's highly influential studies, while also incorporating key ideas from Edward Cone (one of the few early North American music theorists to address issues of form); (2) Jan LaRue's "descriptive" approach, which influenced studies by Eugene K. Wolf, Bathia Churgin, and others; and (3) the "historicist" views of Leonard G. Ratner, whose turning back to eighteenthcentury theorists of form and phrase structure, especially H. C. Koch, inspired significant research by scholars such as Elaine Sisman, Janet Levy, Jane R. Stevens, Mark Evan Bonds, and Karol Berger. Though not so clearly associated with these three traditions, mention must also be made of contributions to nineteenth-century form by the historians James Webster and Anthony Newcomb.

A revival of interest in musical form among theorists of recent decades has been stimulated by a number of research initiatives. In the first instance, some new approaches to musical rhythm and meter have yielded significant insights into matters of form and phrase structure, especially in the writings of William Rothstein, David Beach, and Joel Lester. Second, whereas Schenker's acerbic remarks on the traditional theories of form were a major source of antagonism to the topic, a number of younger Schenkerians - including Charles Smith, Joel Galand, Wayne Petty, Peter Smith, and Poundie Burstein - have begun to reexamine Schenker's own views and analytical approach, with the goal of stimulating new research into matters of musical form. Third, the development and extension of the formal theories of Arnold Schönberg and his students (especially Erwin Ratz), recently espoused by William Caplin, along with studies by Janet Schmalfeldt, has brought a "theory of formal functions" to the attention of the theoretical community. Caplin proposes a wide range of categories (and an attendant terminology) for analyzing 
formal functionality at all levels in the hierarchy of a work in the classical style, giving special attention to the role of cadence in articulating form. Fourth, the collaborative efforts of James Hepokoski and Warren Darcy have resulted in a new genre-based "sonata theory" for the analysis of classical and romantic forms. Key elements of their theory include defining a "medial caesura" within a sonata-form exposition, the notion of "rotational" form, and processes of formal "deformation". In addition to the main developments just outlined, many other theorists in the past several decades have contributed individual studies to the theory and analysis of musical form, including those by Scott Burnham, Ethan Haimo, Jonathan Kramer, Robert Morgan, and David Smyth, to name but a few.

In light of the extraordinary flourishing of formal theory in recent years, the lacuna of research into form that existed at the very time when North American music theory was developing into a distinct academic discipline must be seen as a historical aberration, one that is now in the process of correction. As we begin the twenty-first century, a substantial segment of the theory community is reengaging the topic, often in productive dialogue with music historians. That the 2004 Mannes Institute on Advanced Theoretical Studies would be devoted exclusively to theories of musical form bears witness to the enormous progress that has been achieved in restoring this subject to its rightful place as a legitimate field of music-theoretical reflection.

\section{Bibliography}

Beach, David. 1995. "Phrase Expansion: Three Analytical Studies." Music Analysis 14: 27-47.

Berger, Karol. 1996. "The First-Movement Punctuation Form in Mozart's Piano Concertos." In Mozart's Piano Concertos: Text, Context, Interpretation, edited by Neal Zaslaw. Ann Arbor: University of Michigan Press, 239-59.

Berry, Wallace. 1966. Form in Music. Englewood Cliffs, N. J.: Prentice-Hall; ${ }^{2} 1986$.

Bonds, Mark Evan. 1991. Wordless Rhetoric: Musical Form and the Metaphor of the Oration. Cambridge: Harvard University Press.

Burnham, Scott. 2001. "The Second Nature of Sonata Form." In Music Theory and Natural Order from the Renaissance to the Early Twentieth Century, edited by Suzannah Clark and Alexander Rehding. Cambridge: Cambridge University Press.

Burstein, L. Poundie. 1998. "Surprising Returns: The VII-sharp in Beethoven's op. 18, no. 3, and its Antecedents in Haydn." Music Analysis 17: 295-312.

Caplin, William E. 1986. "Funktionale Komponenten im achttaktigen Satz." Musiktheorie 1: 239-60.

- 1998. Classical Form: A Theory of Formal Functions for the Instrumental Music of Haydn, Mozart, and Beethoven. New York: Oxford University Press.

- 2004. "The Classical Cadence: Conceptions and Misconceptions." Journal of the American Musicological Society 57: 51-117. 
Churgin, Bathia. 1992. "Harmonic and Tonal Instability in the Second Key Area of Classic Sonata Form." In Convention in Eighteenth- and Nineteenth-Century Music: Essays in Honor of Leonard G. Ratner, edited by Wye J. Allanbrook, Janet M. Levy, and William P. Mahrt. Stuyvesant, N.Y.: Pendragon, 23-57.

Cone, Edward T. 1968. Musical Form and Musical Performance. New York: W. W. Norton.

Darcy, Warren. 2001. "Rotational Form, Teleological Genesis, and Fantasy-Projection in the Slow Movement of Mahler's Sixth Symphony." 19th-Century Music 25: 49-74.

— and James Hepokoski. 1997. "The Medial Caesura and Its Role in the EighteenthCentury Sonata Exposition." Music Theory Spectrum 19: 115-54.

— and James Hepokoski. Sonata Theory. New York: Oxford University Press, forthcoming.

Galand, Joel. 2000. "The Large-Scale Formal Role of the Solo Entry Theme in the Eighteenth-Century Concerto." Journal of Music Theory 44: 381-450.

Green, Douglass M. 1965. Form in Tonal Music. New York: Holt, Rinehart and Winston; ${ }^{2} 1979$.

Haimo, Ethan. 1995. Haydn's Symphonic Forms: Essays in Compositional Logic. Oxford: Clarendon Press.

Kramer, Jonathan D. 1988. The Time of Music: New Meanings, New Temporalities, New Listening Strategies. New York: Schirmer.

LaRue, Jan. 1970. Guidelines for Style Analysis. New York: W. W. Norton; ${ }^{2} 1992$.

Lester, Joel. 1986. The Rhythms of Tonal Music. Carbondale: Southern Illinois University Press.

Levy, Janet M. 1981. "Gesture, Form, and Syntax in Haydn's Music." In Haydn Studies, edited by Jens Peter Larsen, Howard Serwer, and James Webster. New York: W. W. Norton, 355-62.

Morgan, Robert P. 2000. "Circular Form in the Tristan Prelude." Journal of the American Musicological Society 53: 69-103.

Newcomb, Anthony. 1987-88. "Schumann and Late Eighteenth-Century Narrative Strategies." 19th-Century Music 11: 164-74.

Petty, Wayne C. 1999. "Koch, Schenker, and the Development Section of Sonata Forms by C. P. E. Bach." Music Theory Spectrum 21: 151-173.

Ratner, Leonard G. 1980. Classic Music: Expression, Form, and Style. New York: Schirmer.

Rosen, Charles. 1972. The Classical Style: Haydn, Mozart, Beethoven. New York: W. W. Norton.

- 1980. Sonata Forms. Rev. ed. New York: W. W. Norton; ${ }^{2} 1988$.

Rothstein, William. 1989. Phrase Rhythm in Tonal Music. New York: Schirmer.

Schmalfeldt, Janet. 1991. "Towards a Reconciliation of Schenkerian Concepts with Traditional and Recent Theories of Form." Music Analysis 10: 233-87. 
- 1995. "Form as the Process of Becoming: The Beethoven-Hegelian Tradition and the 'Tempest' Sonata." Beethoven Forum 4: 37-71.

Sisman, Elaine R. 1982. "Small and Expanded Forms: Koch's Model and Haydn's Music." Musical Quarterly 68: 444-75.

Smith, Charles. 1996. "Musical Form and Fundamental Structure: An Investigation of Schenker's 'Formenlehre'." Music Analysis 15: 191-297.

Smith, Peter H. 1994. "Brahms and Schenker: A Mutual Response to Sonata Form." Music Theory Spectrum 16: 77-103.

Smyth, David. 1993. "'Balanced Interruption' and the Formal Repeat." Music Theory Spectrum 15: 76-88.

Stevens, Jane R. 1992. "Patterns of Recapitulation in the First Movements of Mozart's Piano Concertos." In Musical Humanism and its Legacy: Essays in Honor of Claude Palisca, edited by Nancy Kovaleff Baker and Barbara Russano Hanning. Stuyvesant, N.Y.: Pendragon, 397-418.

Tovey, Donald Francis. 1935-39. Essays in Musical Analysis. 7 vols. London: Oxford University Press.

- 1956. The Forms of Music. New York: Meridian Books.

Webster, James. 1978-79 / 1979-80. "Schubert's Sonata Form and Brahms's First Maturity." 19th-Century Music 2: 18-35; 3: 52-57.

Wolf, Eugene K. 1981. The Symphonies of Johann Stamitz. Utrecht: Bohn, Scheltema \& Holkema. 